\title{
Model Sebaran Limbah Bahang Di PLTU Tanjung Jati B Jepara
}

\author{
Fernandito Suryo Hutomo $^{1 *}$, Aris Ismanto ${ }^{1}$, Heryoso Setiyono ${ }^{1}$, Lilik Maslukah ${ }^{1}$ dan \\ Rikha Widiaratih ${ }^{1}$
}

${ }^{1}$ Departemen Oseanografi, Fakultas Perikanan dan Ilmu Kelautan, Universitas Diponegoro Jl. Prof. H. Sudarto, SH, Tembalang Semarang. 50275 Telp/fax (024)7474698

Email:*1fernanditosuryoh@gmail.com

\begin{abstract}
Abstrak
PLTU Tanjung Jati B sedang menambah unit operasionalnya. Adanya penambahan unit ini akan menambah luasan limbah air panas yang lebih luas dari sebelumnya. Bertambahnya luasan limbah air panas ini memerlukan analisa pola sebarannya untuk dapat mengantisipasi terjadinya kerusakan lingkungan pada perairan sekitarnya. Tujuan dari penelitian ini adalah untuk mengidentifikasi sebaran suhu perairan setelah adanya penambahan unit $5 \& 6$ PLTU Tanjung Jati B Kabupaten Jepara pada musim barat, peralihan I, timur, dan peralihan II. Penelitian ini menggunakan data primer berupa suhu lapangan dan debit simulasi air bahang. Data sekunder berupa pasang surut, batimetri, arus, dan angin. Metode yang digunakan dalam penelitian ini adalah model hidrodinamika adveksi-dispersi dengan menggunakan aplikasi Delft3D. Hasil penelitian ini adalah pola sebaran suhu air bahang akan mengikuti pola arus yang ada, dimana arah sebaran pada Musim Barat dan Peralihan I condong ke arah timur, lalu pada Musim Timur dan Peralihan II condong ke arah barat.
\end{abstract}

Kata kunci : Dispersi Suhu, PLTU, Air Bahang, Delft3D

\begin{abstract}
PLTU Tanjung Jati is planning to add its operational units. The addition of this unit will widen the area of hot water waste. The widening area of hot water waste requires analysis of its distribution patterns to anticipate environmental damage to its sorrounding waters. The purpose of this research is to study the model of water temperature distribution after the addition of units 5 \& 6 PLTU Tanjung Jati B Jepara Regency in the west monsoon, transition I, east, and transition II. This study uses primary data in the form of sea surface temperature and outlet water discharge. Secondary data is in the form of tides, bathymetry, currents, and wind. The method used in this research is the advection-dispersion hydrodynamic model using the Delft3D application. The result of this research is that the distribution pattern of hot water temperature will follow the existing current pattern, where in the West and Transition I monsoons it tends to the east, and then in the East Season and the Transition II monsoons tends to the west.
\end{abstract}

Keywords : Thermal Dispersion, Steam Powerplant, Hot Waste Water, Delft3D

\section{PENDAHULUAN}

Listrik merupakan elemen penting dalam kehidupan masyarakat. Permintaan kebutuhan listrik akan semakin naik seiring dengan pertumbuhan penduduk. PLTU (Pembangkit Listrik Tenaga Uap) adalah salah satu solusi mecukupi kebutuhan listrik yang banyak digunakan di Indonesia. PLTU atau Pembangkit Listrik Tenaga Uap adalah pembangkit yang mengandalkan energi kinetik dari uap untuk menghasilkan energi listrik. Bentuk utama pembangkit listrik ini adalah generator yang dihubungkan ke turbin dimana untuk memutar turbin diperlukan energi kinetik dari uap panas atau kering hasil pembakaran bahan bakar berupa batubara. Dalam turbin uap, energi uap dikonversikan menjadi energi mekanis penggerak generator yang akan menghasilkan energi listrik dari oleh generator (Hetharia dan Lewerissa, 2018)

Umumnya, pembangkit listrik tenaga uap membutuhkan air laut sebagai pendingin. Air laut ini kemudian akan dialirkan kembali ke laut. Air laut yang telah dialirkan kembali ini dinamakan limbah air panas atau sering disebut dengan air bahang karena memiliki suhu relatif lebih tinggi dari perairan sekitar. Penggunaan air pendingin diperuntukkan untuk menghemat dalam penggunaan air bersih dalam 
pemutaran turbin (Sianturi, 2009). Wibowo (2012), dalam Utama et al. (2020), menyatakan bahwa pembuangan limbah air panas ini mengakibatkan kenaikan suhu di sekitar daerah ujung pipa serta mempengaruhi ekosistem perairan dan sirkulasi air lokal. Umumnya suhu air buangan tersebut dapat mencapai 400 C (Utama, 2020). Sedangkan, Peraturan Menteri Negara Lingkungan Hidup No. 8 Tahun 2009 tentang baku mutu air limbah bagi usaha dan atau kegiatan pembangkit listrik, menyatakan bahwa kadar maksimum suhu buangan dari sumber pendingin adalah $400 \mathrm{C}$.

PLTU Tanjung Jati B yang terletak di Kabupaten Jepara, Jawa Tengah merupakan salah satu pembangkit listrik besar di Indonesia yang telah beroperasi sejak tahun 2006. PLTU Tanjung Jati B akan menambah unit operasional, yaitu unit 5 dan 6 yang diharapkan dapat beroperasi pada tahun 2021 . Peraturan Gubernur nomor 660.1/11 tahun 2016, menyatakan bahwa unit operasional ini akan memiliki kapasitas produksi 2 x 1070 MW. Penambahan unit ini akan menambah luasan kegiatan operasional pada perairan sekitar. Hal ini dikarenakan PLTU membutuhkan air laut sebagai pendingin yang setelah itu akan dibuang langsung ke badan perairan dengan suhu yang relatif tinggi (Sianturi, 2009). Sehubungan dengan hal tersebut, dampak pembuangan limbah panas akan semakin meluas.

Subardjo (2015) menyatakan bahwa pembuangan limbah panas tersebut akan memberikan pengaruh terhadap kondisi lingkungan. Kelebihan panas akan merubah suhu perairan dan dapat mempengaruhi ekosistem secara langsung maupun tidak langsung. Perubahan suhu perairan dapat mempengaruhi salinitas perairan terhadap air limbah maupun perairan sekitar.

Penelitian mengnenai sebaran suhu pembuangan air limbah dari PLTU ini diperlukan sebagai salah satu cara pemantauan kondisi lingkungan perairan sekitar (Subardjo, 2015). Tujuan penelitian ini adalah mengidentifikasi sebaran suhu permukaan perairan setelah adanya penambahan unit 5 \& 6 PLTU Tanjung Jati B Kabupaten Jepara pada musim barat, peralihan I, timur, dan peralihan II menggunakan model adveksi dispersi. Karena unit masih dalam tahap konstruksi, pemantauan sebaran suhu pembuangan air limbah dari PLTU dilakukan melalui pendekatan model numerik.
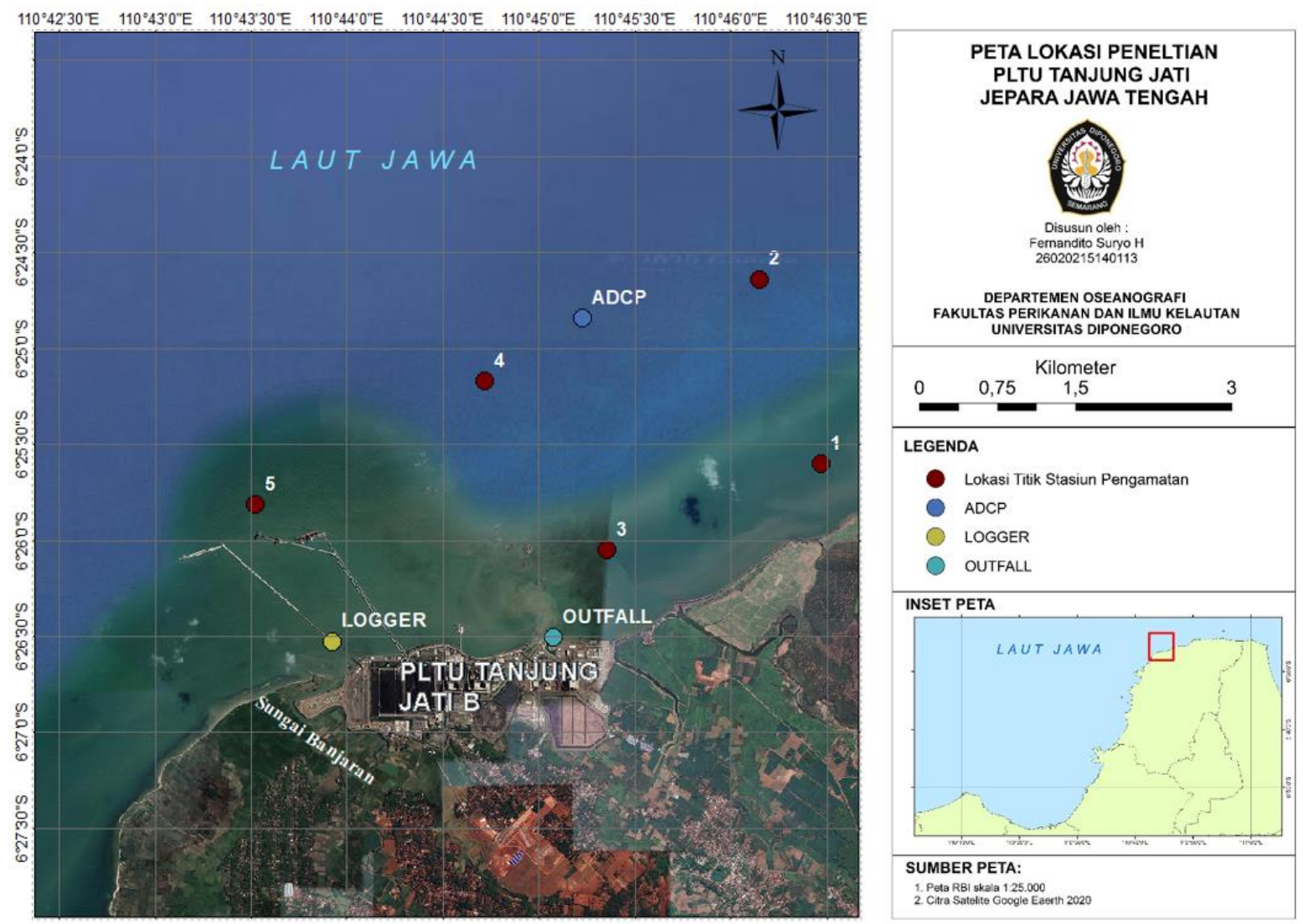

Gambar 1. Peta Lokasi Penelitian 


\section{MATERI DAN METODE}

Materi penelitian yang digunakan berupa data primer dan data sekunder. Data primer adalah data pengukuran lapangan suhu permukaan air laut dan debit air bahang rencana yang keluar dari outlet ke perairan PLTU Tanjung Jati B. Data sekunder dalam penelitian ini adalah data prediksi pasang surut BIG tahun 2020, data angin Marine Copernicus tahun 2020, data batimetri GEBCO pada perairan sekitar PLTU Tanjung Jati B, Jepara. Metode penelitian yang digunakan adalah metode deskriptif. Tujuan dari penelitian metode deskriptif ini adalah untuk mendapatkan gambaran tentang sebaran suhu permukaan laut yang dipengaruhi oleh pembuangan air bahang pada rencana unit 5 dan 6 PLTU Tanjung Jati B, Kabupaten Jepara, Jawa Tengah. Penentuan titik sampling pada penelitian ini didasarkan dengan metode purposive sampling. Metode purposive sampling adalah metode dimana peneliti menentukan titik sampling dengan menetapkan ciri-ciri khusus yang dapat mewakili tujuan penelitian. Pada penelitian ini, titik sampling berdasarkan pertimbangan pada kedalaman dan jarak antar titik.

Metode pengambilan sampel tidak mengambil seluruh sampel sebagai sasaran penelitian, apalagi juka jumlah populasi cukup besar, tetapi cukup dengan meneliti sebagian dari sampel agar sampel yang diambil dapat menggambarkan karakteristik populasi yang diwakili secara representatif, dimana pemilihannya harus memperhatikan syarat-syarat yang harus dipenuhi secara metodologis.

\section{Pemodelan Arus Hidrodinamika}

Pemodelan arus dilakukan untuk mengetahui arah dan kecepatan arus prediksi. Pemodelan ini digunakan untuk melakukan verifikasi dari data arus lapangan. Software yang digunakan dalam pembuatan model adalah Delft3d. Delft3d merupakan software yang dibuat oleh Deltares. (Deltares, 2011). Pemodelan arus pada Delft3d menggunakan modul hidrodinamika yaitu Delft3d-FLOW. Model dalam delft3d diselesaikan dengan pendekatan numerik yaitu metode beda hingga. Model arus ini dibangkitkan oleh pasang surut air laut di Jepara bertepatan dengan pengambilan arus lapangan.

Syarat batas model hidrodinamika adalah :

- Syarat batas tertutup (Daratan)

- Syarat batas terbuka atau open boundary (Lautan)

\section{Verifikasi Hasil Pemodelan Hidrodinamika}

Setelah melakukan pemodelan hidrodinamika untuk menghasilkan data elevasi muka air laut dan pola arus, hal yang perlu dilakukan adalah verifikasi data tersebut dengan data lapangan untuk mengetahui kesesuaian model dengan keadaan sebenarnya. Hal ini dapat dilakukan dengan menghitung nilai RMSE (Root Mean Square Error) dan R-squared nya.

Menurut Septiawan dan Astuti (2016), nilai RMSE merupakan rata-rata besar kesalahan pada suatu sampel data dengan persamaan RMSE yaitu sebagai berikut:

$$
R M S E=\sqrt{\frac{\sum_{i=1}^{n}\left(y_{i}-\hat{y}_{i}\right)^{2}}{n}}
$$

Tabel 1. Interpretasi RMSE

\begin{tabular}{ll}
\hline RMSE & Tingkat Kesalahan \\
\hline $0,00-0,299(0 \%-29,9 \%)$ & Kecil \\
$0,30-0,599(30 \%-59,9 \%)$ & Sedang \\
$0,60-0,899(60 \%-89,9 \%)$ & Besar \\
$>0,9(>90 \%)$ & Sangat Besar \\
\hline
\end{tabular}


Dengan n, $y i, \bar{y} i$ berturut-turut adalah jumlah data, data lapangan dan data hasil pemodelan dan untuk mengetahui kesesuaian dan kualitas dari hasil model dapat mengacu pada interpretasi hasil perhitungan berdasarkan Tabel 1 .

\section{Pemodelan Sebaran Air Bahang PLTU}

Pemodelan sebaran air bahang PLTU dilakukan untuk mengetahui simulasi sebaran limbah panas yang keluar dari outfall. Pemodelan sebaran panas dilakukan menggunakan delft3d dengan modul FLOW. (Deltares, 2011). Model matematis yang digunakan tidak jauh beda dengan model arus. Perbedaan dalam memodelkan arus dan sebaran air limbah panas ialah penambahan modul adveksi dispersi dimana terdapat suatu konsentrasi materi yang bergerak. Konsentrasi materi pada model digantikan oleh suhu permukaan perairan.

Simulasi model sebaran limbah panas dilakukan pada tiap bulan tahun 2020. Simulasi model dibuat dengan asumsi bahwa unit PLTU Tanjung Jati Unit 5 dan 6 sudah beroprasi. Skenario diasumsikan memiliki sebuah outlet dengan debit $91,667 \mathrm{~cm}^{3} /$ detik. Suhu air limbah panas yang keluar diasumsikan sebesar $31{ }^{\circ} \mathrm{C}$. Syarat batas pada model tidak jauh dengan model hidrodinamika arus. Kondisi awal perairan sekitar adalah berupa suhu dan tinggi muka air. Suhu awal perairan diasumsikan sebesar $28{ }^{0} \mathrm{C}$.

\section{HASIL DAN PEMBAHASAN}

\section{Verifikasi Pasang Surut}

Verifikasi elevasi muka air laut atau pasang surut dilakukan dengan membandingkan data elevasi muka air laut hasil pemodelan hidrodinamika dengan data elevasi muka air hasil observasi lapangan yang dimiliki oleh instansi Badan Informasi Geospasial pada periode waktu 7-24 Maret 2020.

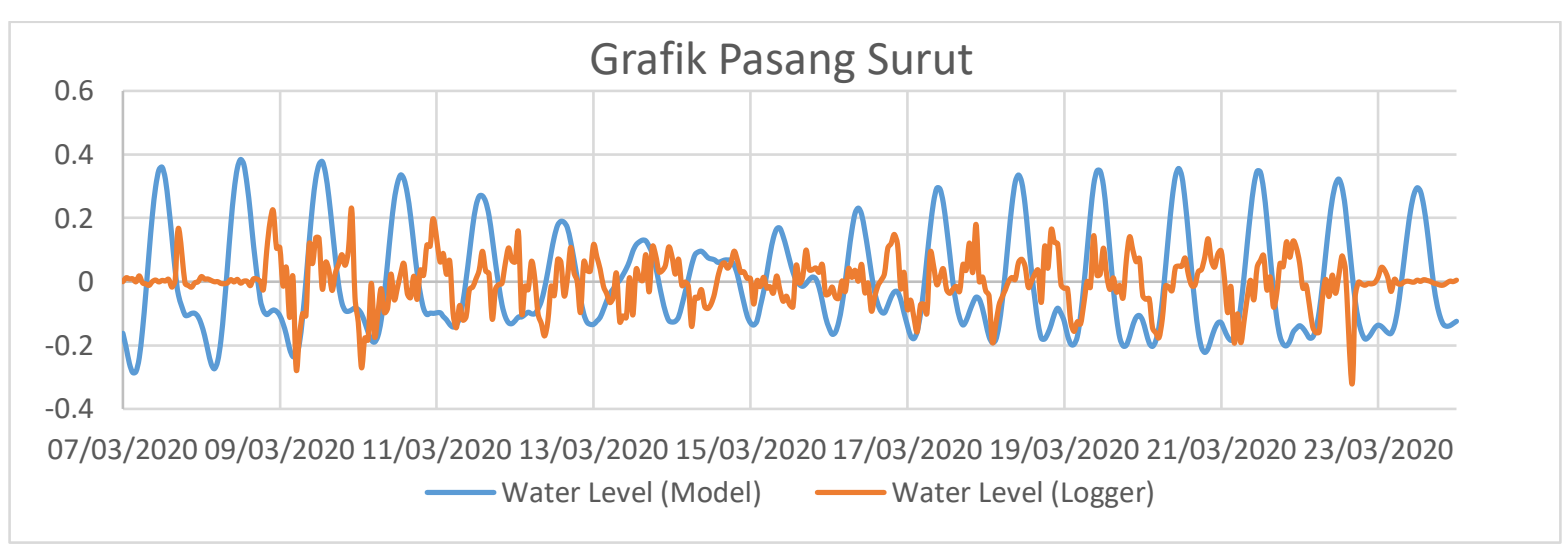

Gambar 2. Grafik Perbandingan Pasang Surut Data Hasil Model vs Observasi

Data elevasi muka air laut hasil pemodelan hidrodinamika (Gambar 2) memiliki kemiripan dengan data elevasi muka air laut hasil observasi lapangan dan menunjukkan pola pasang surut yang sama yaitu campuran condong diurnal. Nilai RMSE yang kecil yaitu 17\% menunjukkan bahwa error data juga kecil. Hasil tersebut menunjukkan bahwa besar magnitudo dan fase dari elevasi muka air laut hasil pemodelan sudah merepresentasikan nilai elevasi muka air laut hasil observasi lapangan. Hal ini menunjukkan ahwa elevasi muka air laut hasil model sudah menggambarkan elevasi muka air laut hasil observasi lapangan sehingga dapat digunakan sebagai syarat batas pemodelan suhu permukaan laut.

\section{Verifikasi Arus}

Verifikasi hasil model arus hidrodinamika dilakukan dengan menggunakan analisis data RMSE. Kecepatan Arus ditinjau dari dua komponen arah, yaitu komponen arah $\mathrm{u}$ dan komponen $\mathrm{v}$ dimana komponen arah u adalah arah pada sumbu $\mathrm{x}$ dan komponen arah v adalah arah pada sumbu y. Grafik 
perbandingan data komponen arus model dengan data komponen arus lapangan dapat dilihat pada Gambar 3 dan Gambar 4.

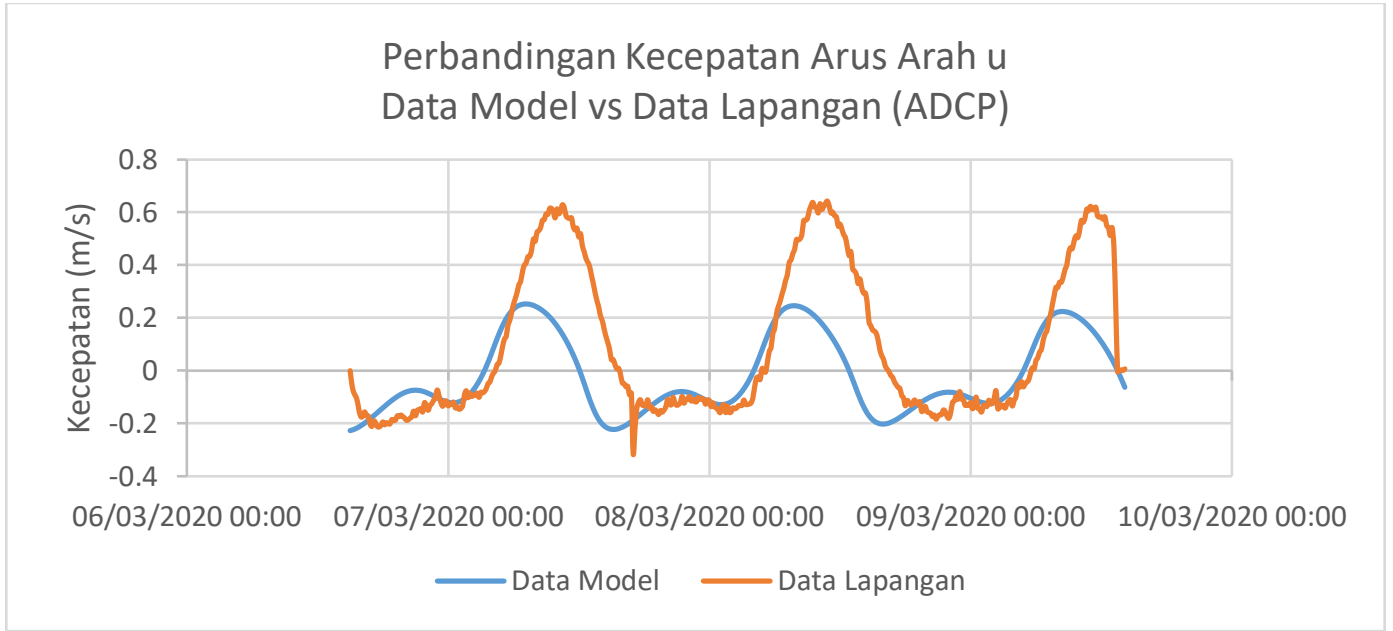

Gambar 3. Grafik Perbandingan Data Model dan Data Lapangan dalam Komponen Arah u

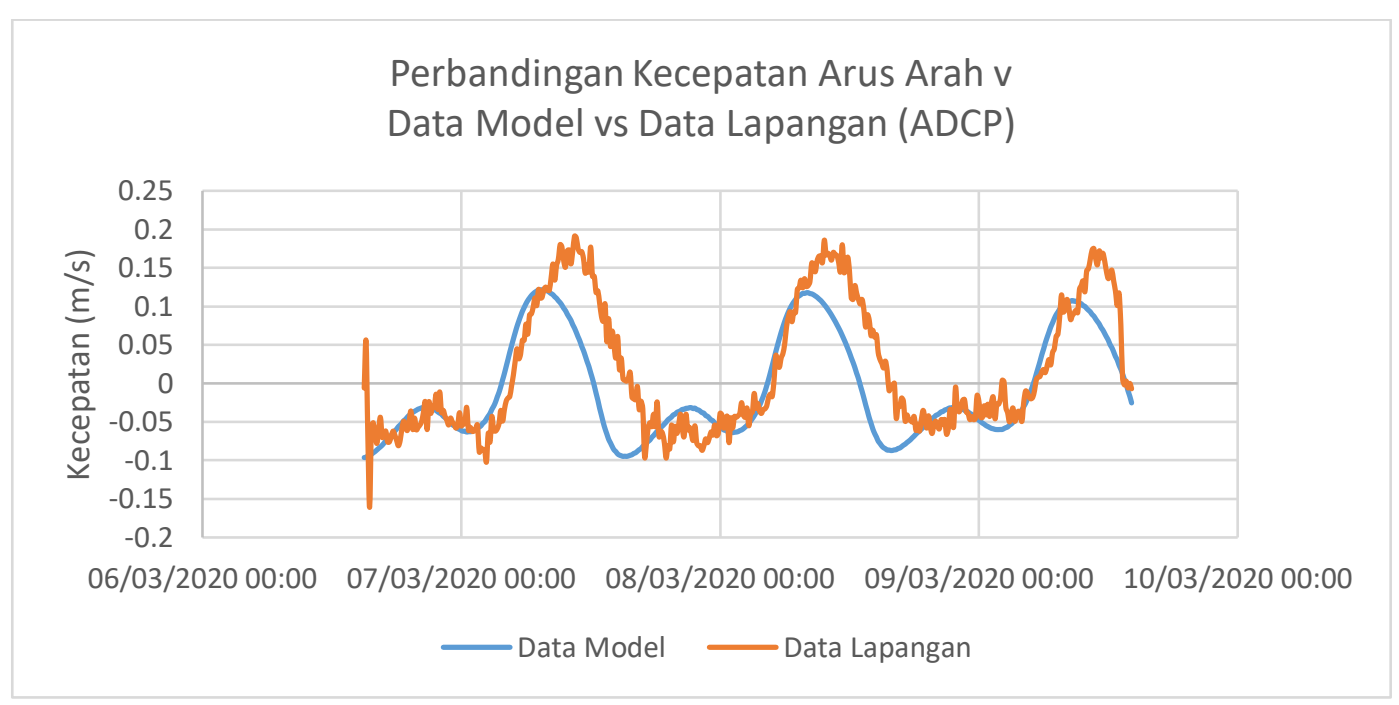

Gambar 4. Grafik Perbandingan Data Model dan Data Lapangan dalam Komponen Arah v

Hasil verifikasi arus model dengan analisis RMSE pada komponen arah u adalah sebesar 23\%, dimana nilai tersebut menunjukkan kesalahan data masuk dalam kategori kecil. Begitu pula dengan arus pada komponen arah $\mathrm{v}$ yang memiliki nilai kesalahan sebesar 6\%, yang masuk kategori kecil. Hasil analisis RMSE pada kedua komponen arah yang kecil menunjukkan bahwa hasil model arus hidrodinamika kurang lebih telah merepresentasikan kondisi arus pada perairan PLTU Tanjung Jati B, Jepara sehingga model dapat menjadi acuan dalam analisa.

\section{Hasil Simulasi Pemodelan Sebaran Suhu}

Hasil simulasi model sebaran suhu berupa luasan persebaran suhu yang keluar dari outfall dengan debit $91,6667 \mathrm{~m}^{3} / \mathrm{s}$ dengan suhu $31^{\circ} \mathrm{C}$. Model sebaran suhu di-overlay dengan model arus untuk mengetahui perbandingan arah sebaran suhu dan arah arus. Hasil simulasi pemodelan sebaran suhu ditampilkan pada kondisi pasang purnama dan pasang perbani pada tiap-tiap bulan nya. Tiap kondisi dibagi pada 4 skenario, yaitu surut menuju pasang tertinggi, pasang tertinggi, pasang menuju surut terendah, dan surut terendah. 


\section{Pasang Purnama}

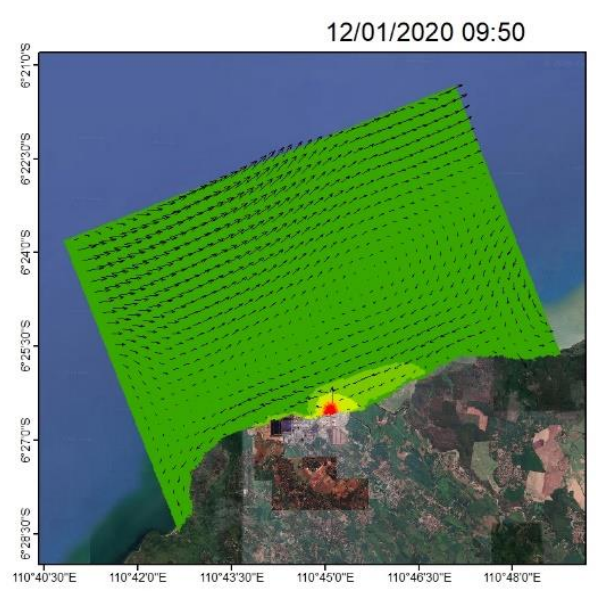

a)

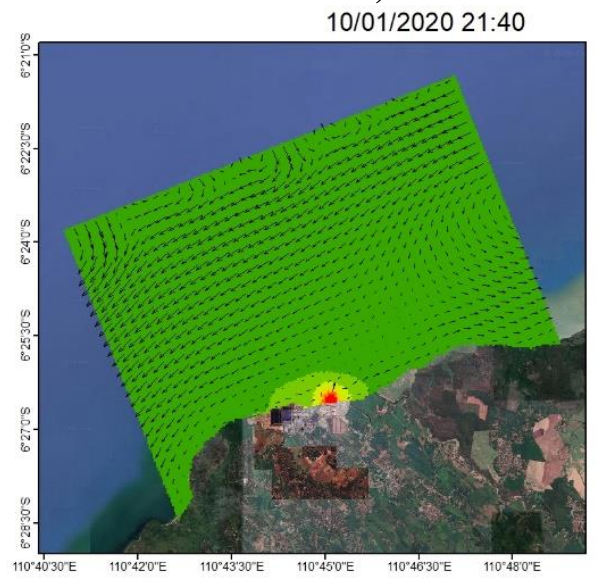

c)



b)

11/01/2020 05:00

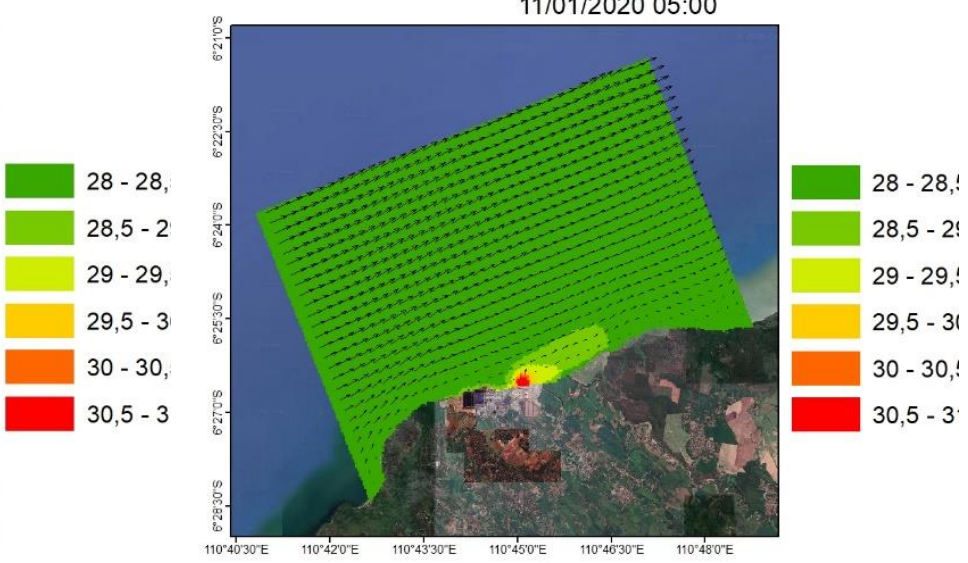

d)

Gambar 5. Pola Arus Bulan Januari Kondisi Pasang Purnama: a) Surut Menuju Pasang, b) Pasang Tertinggi, c) Pasang Menuju Surut, d) Surut Terendah

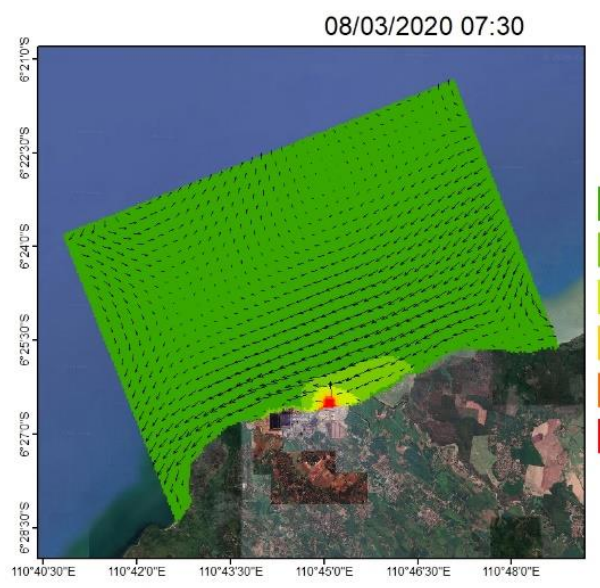

a)

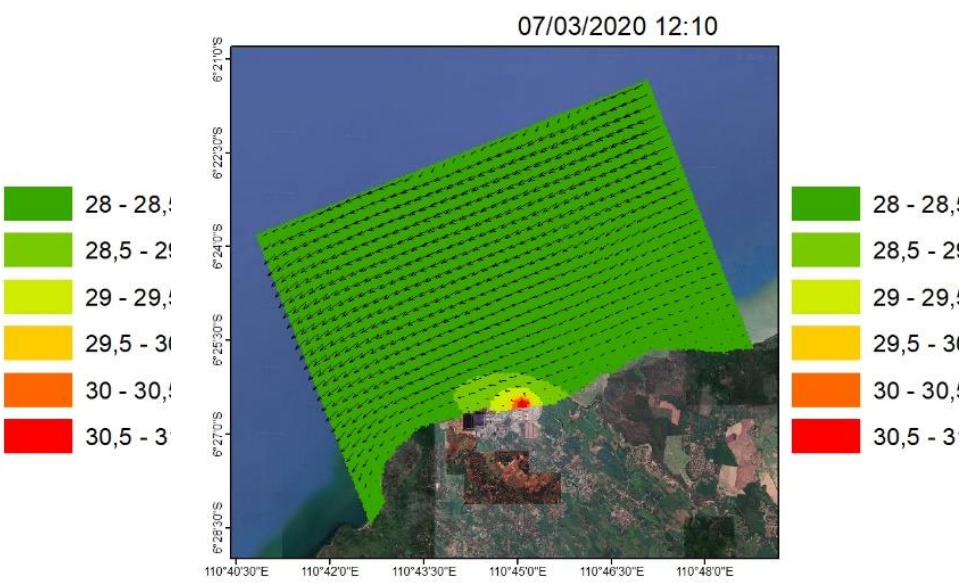

b) 


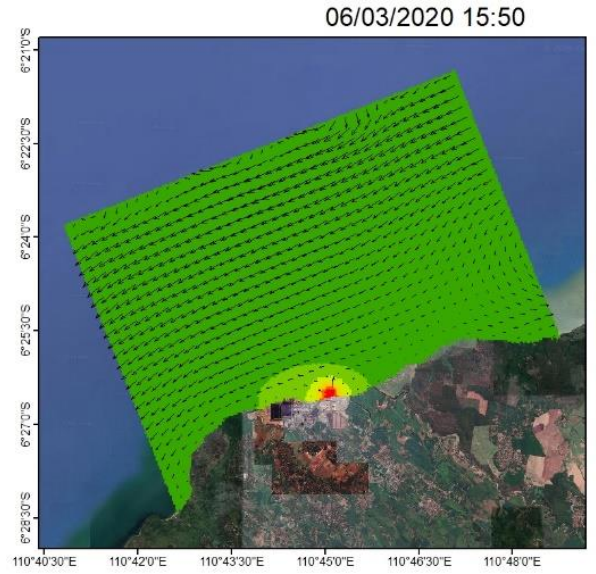

c)

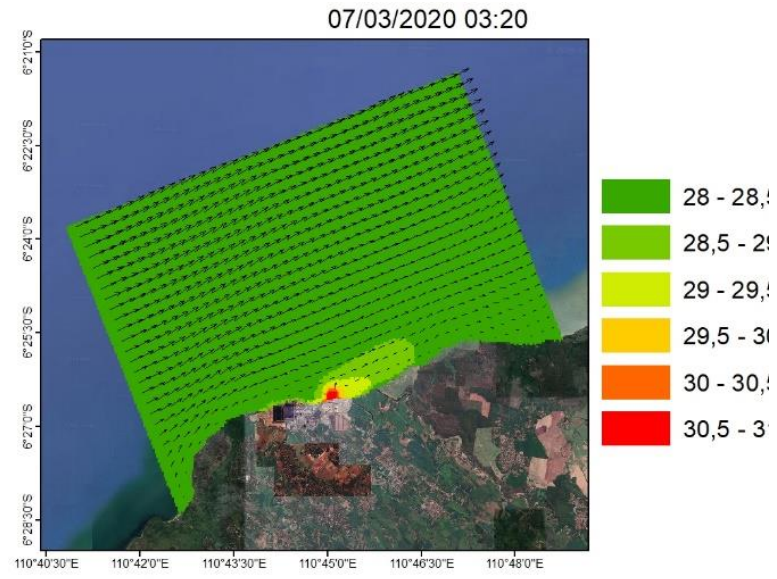

d)

Gambar 6. Pola Arus Bulan Maret Kondisi Pasang Purnama: a) Surut Menuju Pasang, b) Pasang Tertinggi, c) Pasang Menuju Surut, d) Surut Terendah

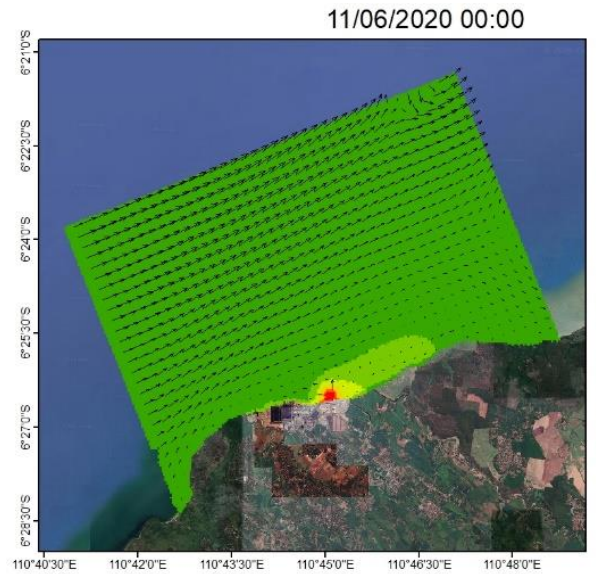

a)

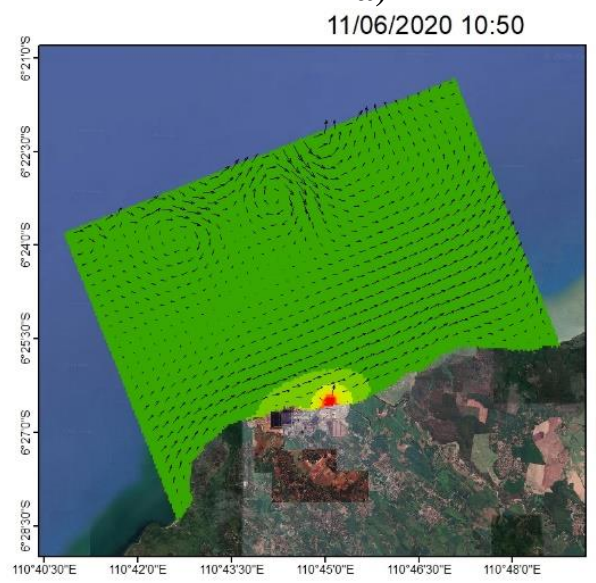

c)

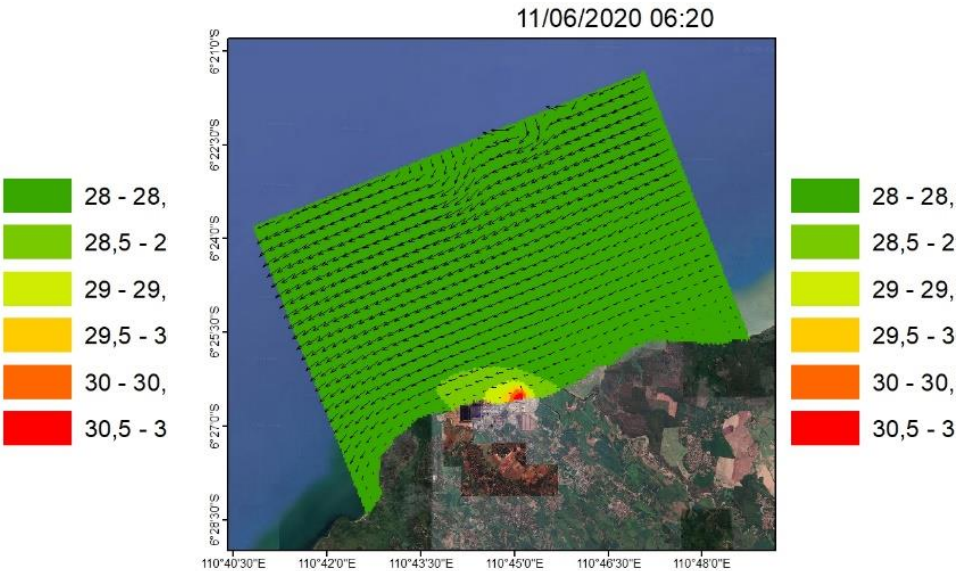

b)

06/01/2020 23:10



d)

Gambar 7. Pola Arus Bulan Juni Kondisi Pasang Purnama: a) Surut Menuju Pasang, b) Pasang

Tertinggi, c) Pasang Menuju Surut, d) Surut Terendah 

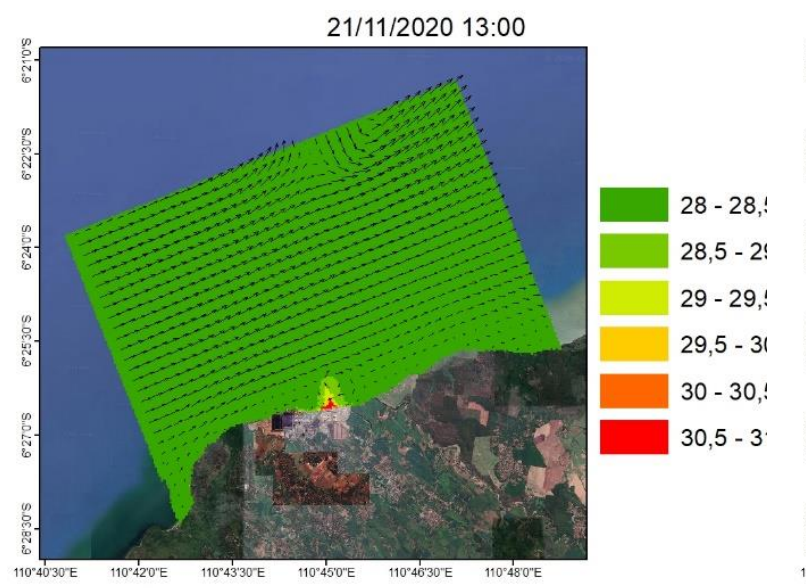

a)

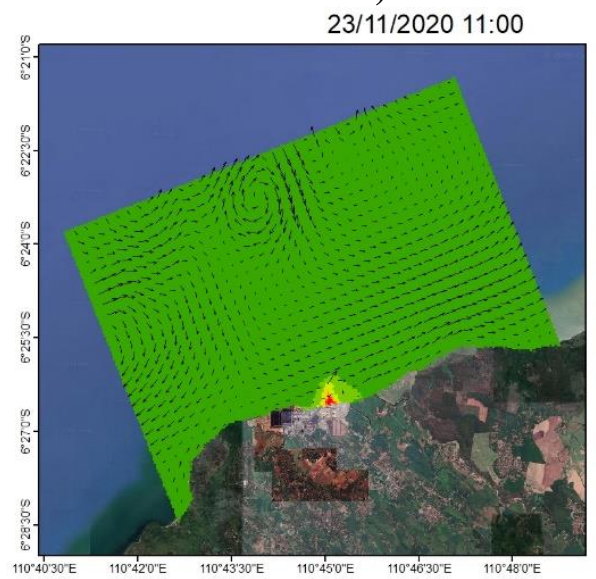

c)

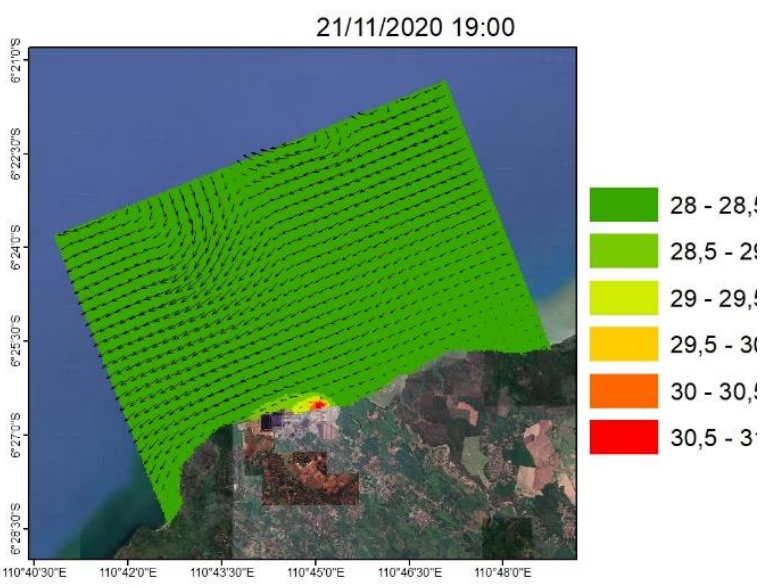

b)

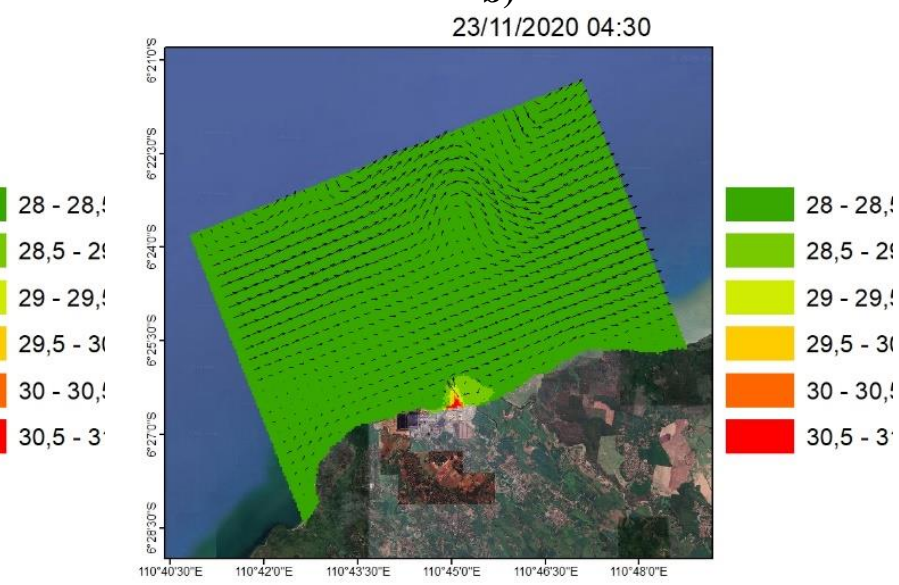

d)

Gambar 8. Pola Arus Bulan November Kondisi Pasang Purnama: a) Surut Menuju Pasang, b) Pasang Tertinggi, c) Pasang Menuju Surut, d) Surut Terendah

\section{Pasang Perbani}

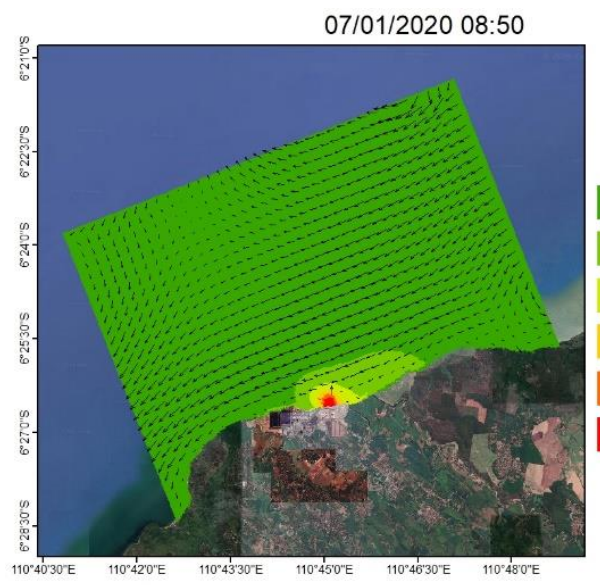

a)

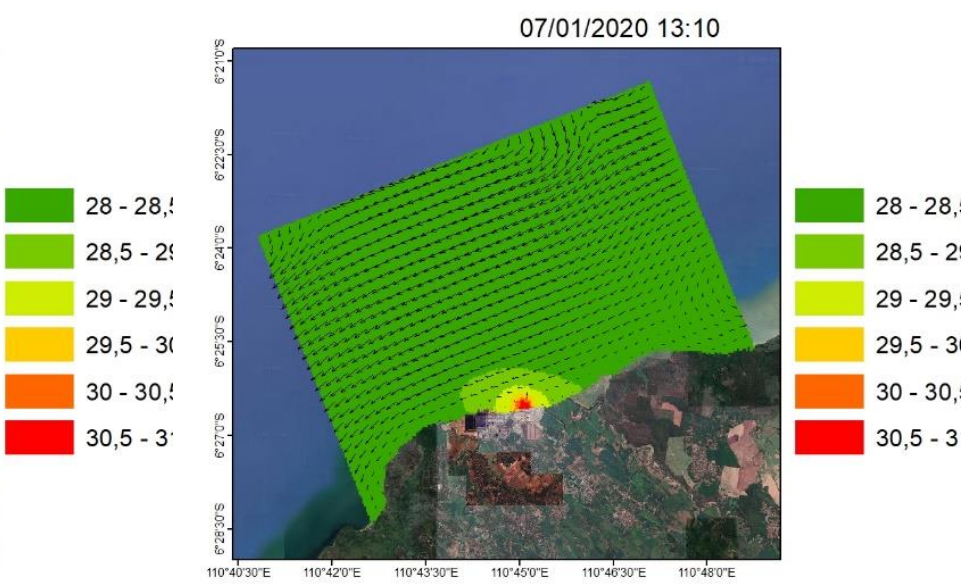

b) 


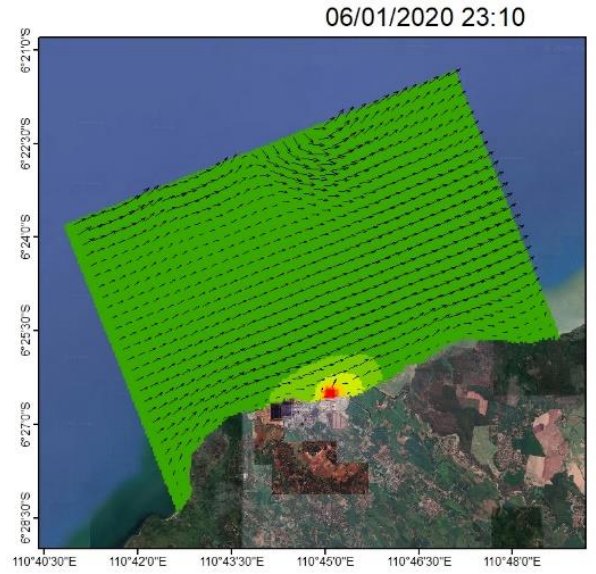

c)

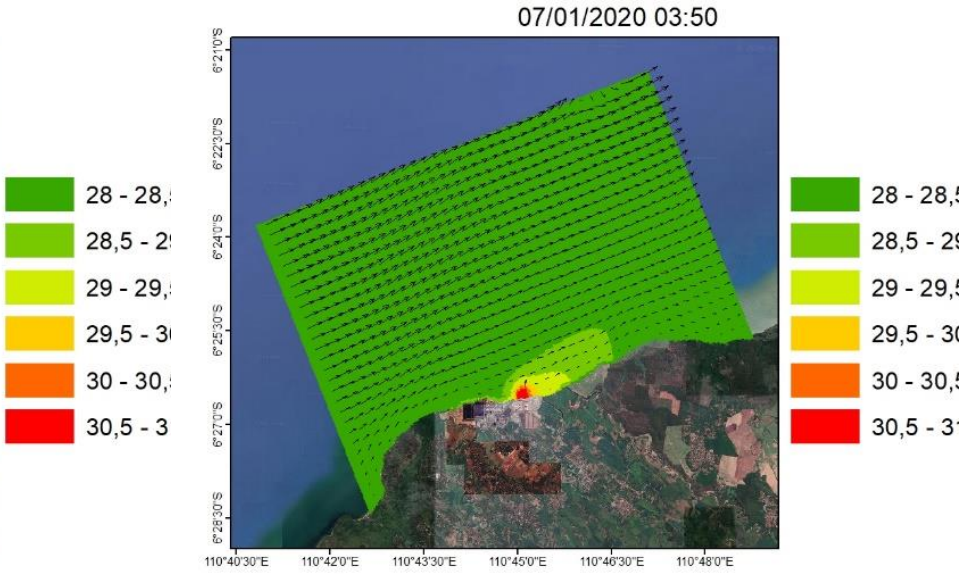

d)

Gambar 9. Pola Arus Bulan Januari Kondisi Pasang Perbani: a) Surut Menuju Pasang, b) Pasang Tertinggi, c) Pasang Menuju Surut, d) Surut Terendah

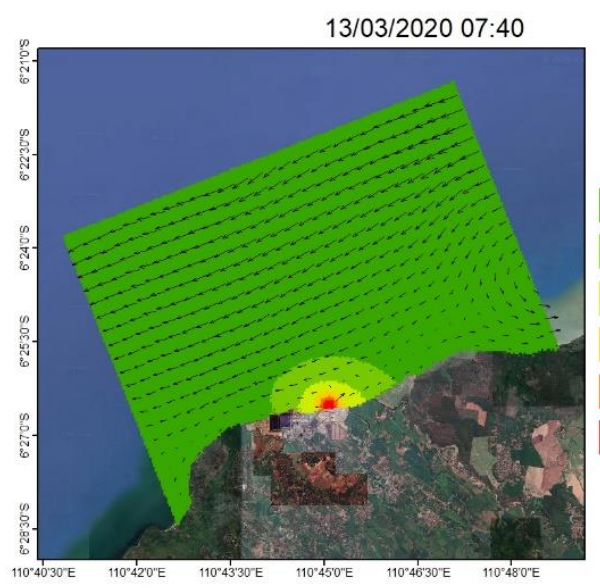

a)



c)

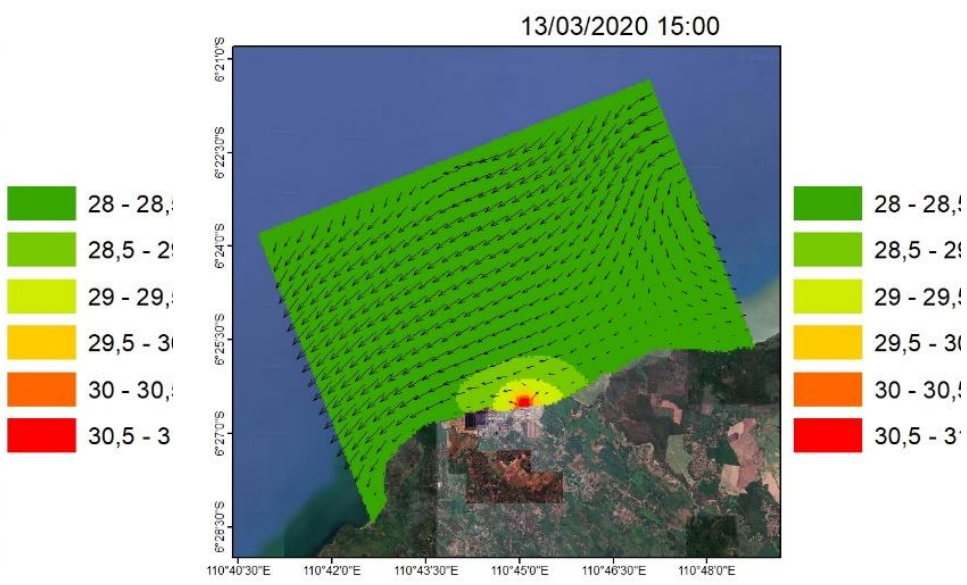

b)

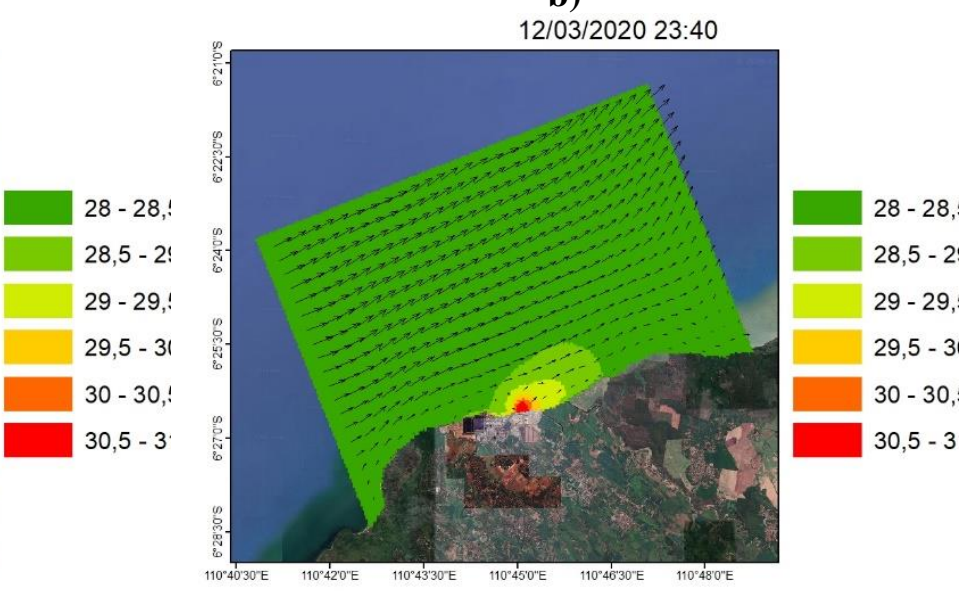

d)

Gambar 10. Pola Arus Bulan Maret Kondisi Pasang Perbani: a) Surut Menuju Pasang, b) Pasang

Tertinggi, c) Pasang Menuju Surut, d) Surut Terendah 

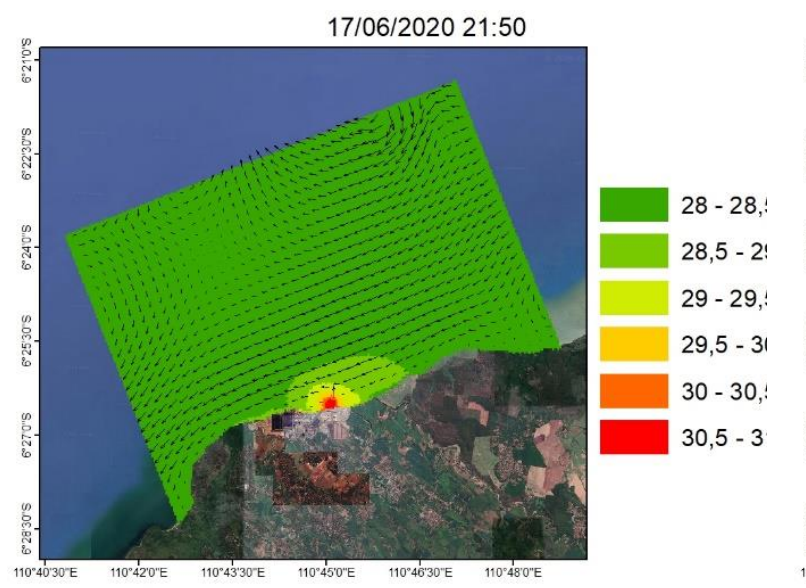

a)

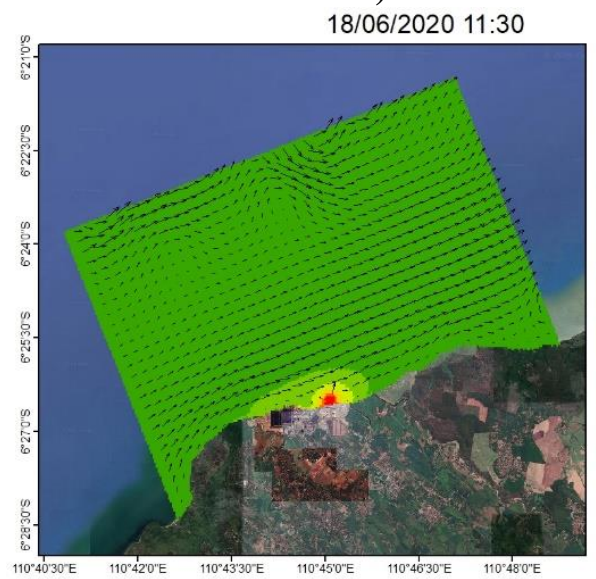

c)

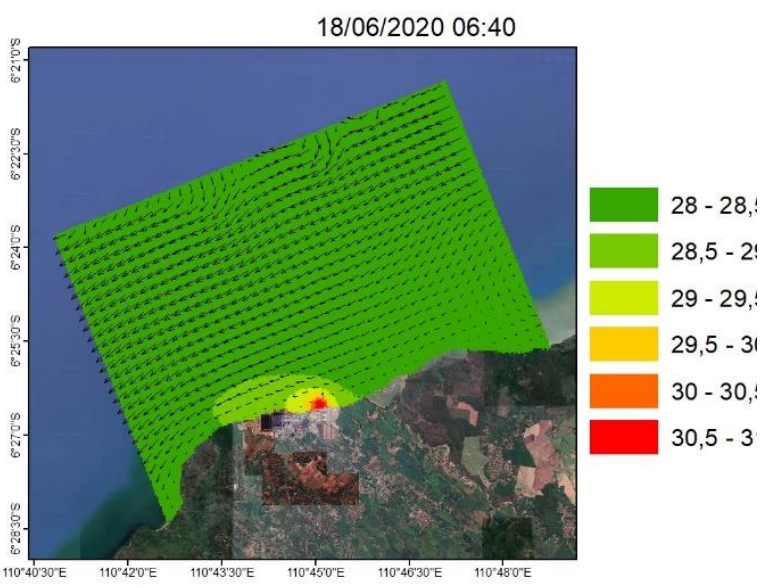

b)

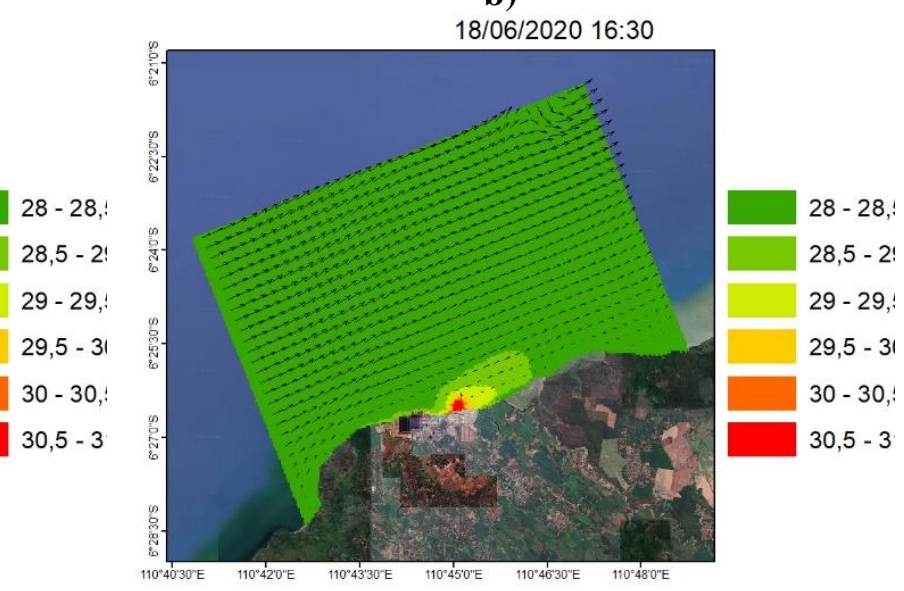

d)

Gambar 11. Pola Arus Bulan Juni Kondisi Pasang Perbani: a) Surut Menuju Pasang, b) Pasang Tertinggi, c) Pasang Menuju Surut, d) Surut Terendah

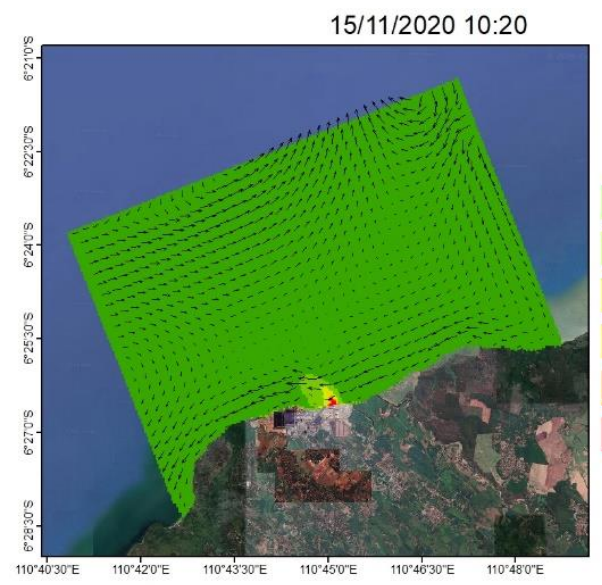

a)

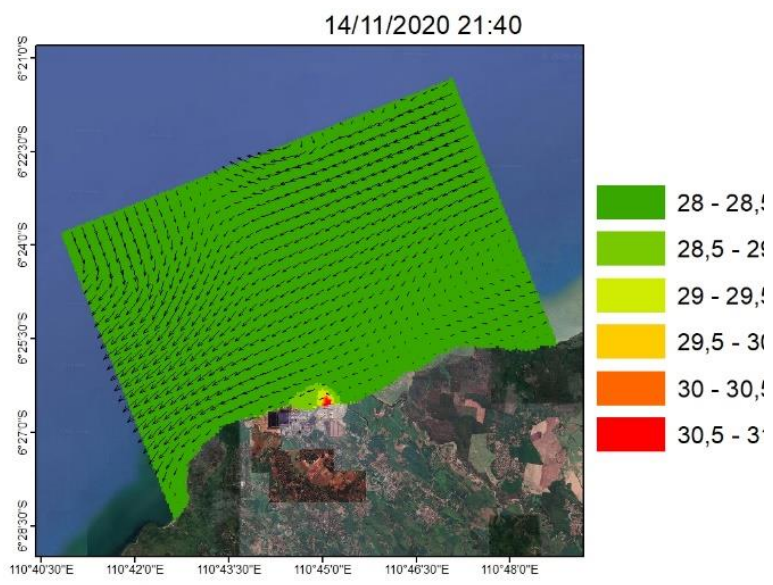

b) 


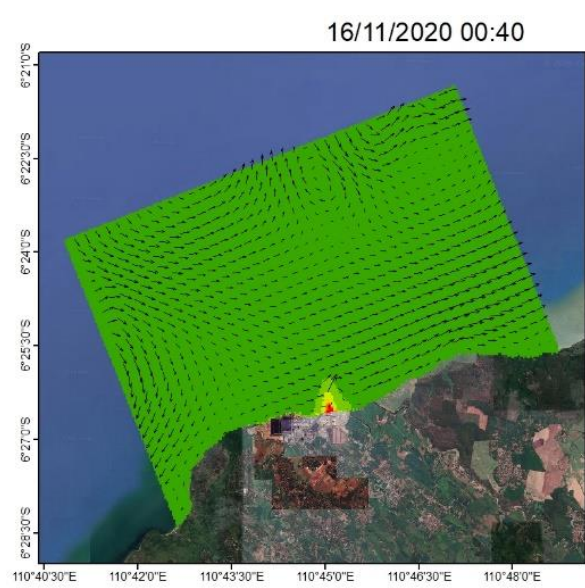

c)

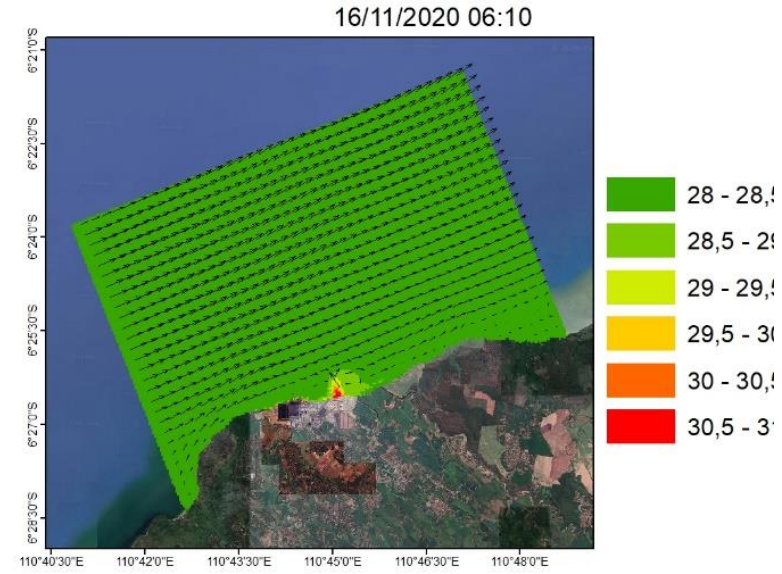

d)

Gambar 12. Pola Arus Bulan November Kondisi Pasang Perbani: a) Surut Menuju Pasang, b) Pasang Tertinggi, c) Pasang Menuju Surut, d) Surut Terendah

\section{Validasi Suhu Lapangan}

Validasi data lapangan digunakan untuk mengetahui validnya data hasil pemodelan. Validasi data model sebaran suhu ditujukkan pada Tabel 2. Hasil validasi menunjukkan nilai error dan nilai kesalahan relatif rata-rata [Mean Relative Error (MRE)] adalah 1,49 \%. Menurut hasil perhitungan nilai MRE, nilai MRE dari data suhu model sudah sangat baik. Sehingga data dapat digunakan untuk analisa lebih lanjut. Menurut Purwadi (2001) dalam Angga (2015), validasi data lapangan tidak boleh menunjukkan hasil MRE kurang dari 30\%, apabila hasil validasi menunjukkan lebih dari $30 \%$ maka perlu adanya pengulangan dan perbaikan model.

Tabel 2. Validasi Data Lapangan

\begin{tabular}{lrrll}
\hline Stasiun & Tanggal & $\begin{array}{c}\text { Data } \\
\text { Model }\end{array}$ & $\begin{array}{c}\text { Data } \\
\text { Lapangan }\end{array}$ & RE \\
\hline 1 & $06 / 03 / 2020$ & 28.0916 & 28.06666667 & 0.000888361 \\
1 & $07 / 03 / 2020$ & 28.1197 & 27.83333333 & 0.010288623 \\
1 & $08 / 03 / 2020$ & 28.1833 & 28.6 & 0.01456993 \\
1 & $09 / 03 / 2020$ & 28.0968 & 28.5 & 0.014147368 \\
2 & $06 / 03 / 2020$ & 28.0063 & 27.33333333 & 0.024620732 \\
2 & $07 / 03 / 2020$ & 28.0107 & 27.5 & 0.018570909 \\
2 & $08 / 03 / 2020$ & 28.0242 & 28.5 & 0.016694737 \\
2 & $09 / 03 / 2020$ & 28.0125 & 27.56666667 & 0.016172914 \\
3 & $06 / 03 / 2020$ & 28.3767 & 28.93333333 & 0.019238479 \\
3 & $07 / 03 / 2020$ & 28.3925 & 28.6 & 0.007255245 \\
3 & $08 / 03 / 2020$ & 28.4193 & 28.43333333 & 0.000493552 \\
3 & $09 / 03 / 2020$ & 28.4176 & 28.93333333 & 0.017824885
\end{tabular}




\begin{tabular}{lllll}
4 & $06 / 03 / 2020$ & 28.0602 & 28.16666667 & 0.003779882 \\
4 & $07 / 03 / 2020$ & 28.0773 & 28.5 & 0.014831579 \\
4 & $08 / 03 / 2020$ & 28.1 & 28.33333333 & 0.008235294 \\
4 & $09 / 03 / 2020$ & 28.0808 & 28.26666667 & 0.006575472 \\
5 & $06 / 03 / 2020$ & 28.1439 & 27.53333333 & 0.022175545 \\
5 & $07 / 03 / 2020$ & 28.1304 & 27.66666667 & 0.016761446 \\
5 & $08 / 03 / 2020$ & 28.1152 & 27.13333333 & 0.036186732 \\
5 & $09 / 03 / 2020$ & 28.1325 & 27.6 & 0.019293478 \\
\hline
\end{tabular}

\section{Pembahasan}

Pola sebaran suhu air bahang berdasarkan model Musim Barat, Musim Peralihan I, Musim Timur, dan Musim Peralihan II memiliki sebaran suhu air bahang yang sama pada kondisi pasang maupun surut. Pada kondisi pasang sebaran suhu air bahang dominan menuju arah barat daya. Sedangkan, pada kondisi surut, sebaran suhu air bahang didominasi menuju arah timur laut.

Pola sebaran suhu air bahang di daerah stasiun titik pengamatan ditinjau pada kondisi surut menuju pasang. tertinggi, pasang tertinggi, pasang menuju surut. terendah, dan surut terendah. Pada kondisi pasang, pola sebaran suhu air bahang dominan menuju arah barat daya. Pola sebaran suhu air bahang cenderung mengikuti pola arus yang ada. Begitu pula pada kondisi surut dimana pola sebaran suhu air bahang searah dengan pola arus yang menuju arah timur sampai timur laut. Menurut Huboyo dan Zaman (2007), pola sebaran suhu air bahang searah dengan pola arus yang ada. Wibowo et al. (2012), pola sebaran suhu air bahang yang mengikuti pergerakan arus disebut proses adveksi. Sedangkan, persebaran suhu air bahang terjadi karena perbedaan gradien suhu di perairan dimana suhu akan bergerak dari suhu tinggi menuju suhu yang lebih rendah.

Berdasarkan hasil simulasi model, dapat diketahui bahwa pada kondisi pasang perbani dan pasang purnama, persebaran suhu air bahang menunjukkan kecepatan pergerakan yang berbeda yang dipengaruhi oleh kecepatan arus. Menurut Setyawan dan Pamungkas (2017), arus merupakan hasil dari bentuk hidrodinamika yang dipengaruhi oleh perbedaan tinggi muka air laut (pasang surut). Arus dipermukaan dipengaruhi oleh pasang surut dan angin (Sugianto et al., 2012). Pasang penuh terbentuk karena akumulasi tarik-menarik lunar dan matahari dalam garis lurus. Pernyataan ini didukung oleh Ismanto et al., (2019) yang menyatakan bahwa rotasi bumi dan posisi relatif bumi terhadap bulan dan matahari mempengaruhi pasang surut laut.

Pada saat pasang surut kuat, maka kecepatan dari arus menjadi lebih cepat juga. Saat pasang purnama kecepatan arus juga lebih kuat dibandingkan saat pasang perbani. Hal ini disebabkan pada saat pasang purnama, posisi Bumi- Bulan-Matahari berada dalam garis lurus sehingga gaya gravitasi BumiBulan-Matahari menjadi lebih kuat dan menyebabkan gradien elevasi lebih besar sehingga kecepatan arus pun lebih besar (Prasetyawan et al., 2019), sehingga menyebabkan persebaran suhu air bahang menunjukan pergerakan yang lebih cepat saat Spring Tide dibandingkan saat Neap Tide.

\section{KESIMPULAN}

Kesimpulan dari penelitian ini adalah hasil simulasi sebaran suhu air bahang perairan sekitar PLTU Tanjung Jati B menunjukkan bahwa pola sebaran suhu air bahang pada Musim Barat, Musim Peralihan I, Musim Timur, dan Musim Peralihan II memiliki sebaran suhu air bahang yang bervsariasi pada kondisi pasang maupun surut dan mengikuti pola arus yang ada. Hasil yang didapat pada musim 
Barat dan Peralihan 1 arah sebaran condong ke arah timur, sedangkan Musim Timur dan Peralihan II condong ke arah barat.

\section{DAFTAR PUSTAKA}

Deltares. 2011. Functional Specications Delft3D. Netherlands: Deltares

Huboyo, H., dan Zaman, B., 2007. Analisis Sebaran Temperatur Dan Salinitas Air Limbah Pltu-Pltgu Berdasarkan Sistem Pemetaaan Spasial (Studi Kasus : Pltu-Pltgu Tambak Lorok Semarang). Jurnal Presipitasi : Media Komunikasi Dan Pengembangan Teknik Lingkungan, [Online] Volume 3(2), Pp. 40-45.

Hetharia, M. dan Y. J. Lewerissa. 2018. Analisis Energi Pada Perencanaan Pembangkit Listrik Tenaga Uap (Pltu) Dengan Cycle Tempo. Jurnal Voering, vol. 3, no. 1, p. 23, 2018.

Ismanto, A., D.H., Ismunarti. D.N., Sugianto. S., Maesyarah. P., Subardjo. Suryoputro, A. A. D. dan H., Siagian. 2019. The Potential of Ocean Currentas Electrical Power Sources Alternatives in Karimunjawa Islands Indonesia. ASTES, 4(6): 126-133.

Prasetyawan, I. B., H. Setiyono., Kunarso., Purwanto., Wijaya Y. J., Helmi M., dan Ismanto A. 2019. Study of Ocean Currents and Their Effect on Distribution of Total Suspended Sediment in Coastal Waters, Semarang. International Journal of Civil Engineering and Technology (IJCIET), 10 (4): 248-259.

Septiawan, R.B. dan Astuti E. Z., 2016. Perbandingan Metode Setengah Rata-Rata Dan Metode Kuadrat Terkecil Untuk Peramalan Pendapatan Perusahaan Di BLU UPTD Terminal Mangkang Semarang. Techno.COM, 15(2): 132-139.

Setyawan, W.B. dan Pamungkas A. 2017 Perbandingan Karakteristik Oseanografi Pesisir Utara Dan Selatan Pulau Jawa: Pasang-surut, Arus, dan Gelombang. Dalam: Prosiding Seminar Nasional Kelautan dan Perikanan III Universitas Trunojoyo, Madura, Jawa Timur.

Sianturi, Ronny Samuel. 2009. Studi Pembangkit Listrik Tenaga Uap Dan Pembangkit Listrik Tenaga Diesel Aplikasi PT. Musim Mas Kim Ii Medan (Skripsi). Program Pendidikan Sarjana Extension, Universitas Sumatra Utara, Medan, $135 \mathrm{hlm}$

Subardjo, Petrus Dan Ario R., 2015. Penyebaran Limbah Air Panas PLTU Di Kolam Pelabuhan Semarang. Jurnal Kelautan Tropis., 19(1): 48-54

Utama, M., Handoyo, G., Setiyono, H., Ismunarti, D., and Suryoputro, A., 2020. Analisa Sebaran Suhu Permukaan Laut Berdasarkan Citra Landsat-8 TIRS di Sekitar Outfall PLTU Tarahan Lampung Selatan. Indonesian Journal of Oceanography, [Online] Volume 2(1), pp. 90 - 97.

Wibowo, Mardi dan Velly A., 2018. Kajian Dispersi Panas Akibat Air Limbah Rencana Pembangunan PLTU Kuala Tungkal Provinsi Jambi. BPPT. Jakarta

Wibowo, N. T., Nugroho Sugianto, D., And Indrayanti, E., 2012. Studi Model Persebaran Panas Pada Perairan Dalam Rencana Pembangunan Pltu Karanggeneng Roban, Batang. Journal of Oceanography, [Online] Volume 1(2), Pp. 102-110. 